\title{
Dr. M.C. Maheshwari (April 19, 1939-January 14, 2018)
}

\author{
Vinod S. Saxena ${ }^{1}$ Man Mohan Mehndiratta ${ }^{2}$ \\ 1Secretary General, IEA-18 International EC Trust, India \\ 2Janakpuri Super Speciality Hospital, Janakpuri, Delhi, India \\ Int J Epilepsy 2018;5:56-56
}

Dr. M. C. Maheshwari died on January 14, 2018, after a short illness. He was born in Saharanpur on April 19, 1939, and after meritorious school and premedical studies, he joined the K.G. Medical College, Lucknow, for his MBBS in 1956. He qualified MD in 1963.

After nearly 5 years of residency at the K.G. Medial College Hospital, Lucknow, he went to the Temple University, Philadelphia, where he worked in neurophysiology and clinical neurology. He later shifted to Birmingham, United Kingdom, to continue his work in various fields of neurology.

"Mool must join us for a meal in the evening," said Prof. Peter Jeavons, then Senior Consultant in Neurology at the Dudley Road Hospital and Aston University in Birmingham. Mool was Dr. Maheshwari. This happened in 1976 when I called on Prof. Jeavons who was designated the lead investigator for valproate by the Committee for the Safety of Medicines, United Kingdom. Not many people called him by his first name. This was my first introduction to him in 1976 after which we continued to meet each other.

He returned to India and worked as the Head of Neurology in Safdarjang Hospital, New Delhi, from 1976 to 1979 when he joined AIIMS as the Associate Professor of Neurology. He became full Professor and Head of Neurology in 1984. He contributed to the all-round development of the department on clinical side, academics, and subspecialties. Under his care, the department flourished to one of all-round excellence and repute, an apt tribute to his devotion and hard work.

I recall his interest in clinical research even when the local infrastructure did not permit. He was an ardent adherent to the concept of affordability in this land teeming with millions of poor. For him economic suitability often won over all other aspects. Phenobarbitone and valproate were on two ends of affordability, and he wished to establish if the two could be co-administered in suitable cases to reduce the total cost of treatment. He established therapeutic drug monitoring to gain indicators for such use in India.

His keen interest in epilepsy led to him being designated the Organizing Secretary for the 18th International Epilepsy Congress (IEC), New Delhi, held in 1989-the first such congress in India. Two or three years before the Congress and some years after, I got an opportunity to work closely with him in India and with the International League Against Epilepsy (ILAE) and the International Bureau of Epilepsy (IBE) outside. The Congress turned out to be a landmark for us in India as its success was unquestionable. It was a worthwhile journey to bring together all groups of interest in India. The financial gains from the Congress were duly converted to the corpus of the IEA-18th IEC Trust in 1992. This Trust continues its

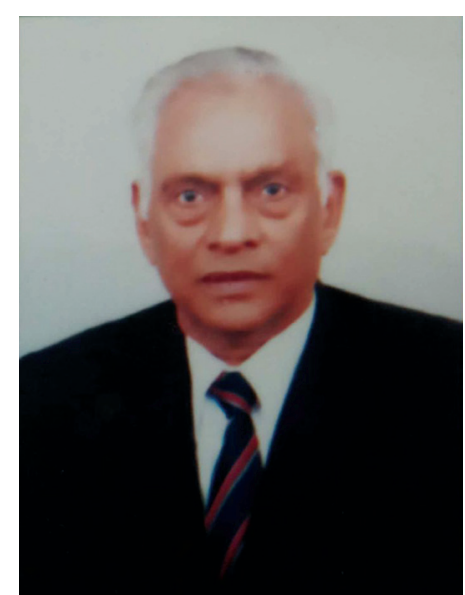

Dr. M. C. Maheshwari charitable work for the benefit of all working for epilepsy. Dr. Maheshwari worked as a trustee from 1992 to 2008.

He kept up his hard work for a separate body for medical aspects of epilepsy through local and international bodies. Thus, the Indian Epilepsy Society came into existence in 1997 where he was a founder member and secretary and remained active for many years. He worked with enthusiasm for the Asian Oceanian Epilepsy Association (AOEA) as he organized its second regional conference in 2000 in New Delhi. This again was a success contributing to the cause of epilepsy and further enrichment of the corpus of the Trust.

He diligently worked to abstract all articles published in the Journal of Neurology India in the first 35 years as he brought out two volumes. He published more than 250 articles in national and international journals. His keen interest in educating public resulted in publication of booklets on epilepsy, stroke, and similar common conditions through the National Book Trust.

The government of India recognized his contribution in the field of medical sciences and conferred on him the award of Padma Shri in 2001.

After retirement from AIIMS in 2001, he pursued his interest in epilepsy and general neurology as a Senior Consultant at VIMHANS, New Delhi, which he continued till a few months before his demise.

Dr. Maheshwari is survived by his wife Mrs. Shashi Maheshwari, daughter Dr. Anupama, and son Dr. Kaushik, with their respective spouses and three grandchildren.

We pray for peace to the departed soul.

\author{
Address for correspondence \\ Man Mohan Mehndiratta, MD, DM, \\ FRCP, Director, Janakpuri Super \\ Speciality Hospital Society, 1st Floor, \\ C28, Janakpuri, Delhi 110058 \\ (e-mail: mmehndi@yahoo.com).
}

DOI https://doi.org/ 10.1055/s-0038-1667411. ISSN 2213-6320.
Copyright (C2018 Indian Epilepsy Society
License terms

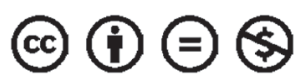

